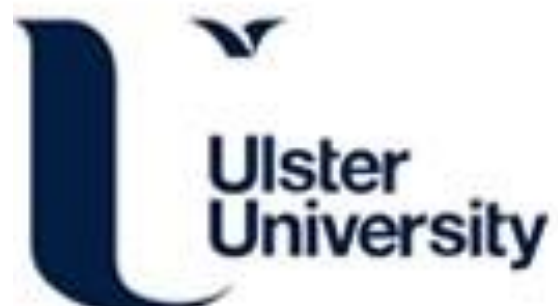

Endothelial cell growth on silicon modified hydrogenated amorphous carbon thin films

Ogwu, AA., Okpalugo, TIT., Ali, N., Maguire, PD., \& McLaughlin, JAD. (2008). Endothelial cell growth on silicon modified hydrogenated amorphous carbon thin films. Journal of Biomedical Materials Research Part B: Applied Biomaterials, 85B(1), 105-113. https://doi.org/10.1002/jbm.b.30922

Link to publication record in Ulster University Research Portal

Published in:

Journal of Biomedical Materials Research Part B: Applied Biomaterials

Publication Status:

Published (in print/issue): 01/04/2008

DOI:

10.1002/jbm.b.30922

Document Version

Publisher's PDF, also known as Version of record

\section{General rights}

Copyright for the publications made accessible via Ulster University's Research Portal is retained by the author(s) and / or other copyright owners and it is a condition of accessing these publications that users recognise and abide by the legal requirements associated with these rights.

\section{Take down policy}

The Research Portal is Ulster University's institutional repository that provides access to Ulster's research outputs. Every effort has been made to ensure that content in the Research Portal does not infringe any person's rights, or applicable UK laws. If you discover content in the Research Portal that you believe breaches copyright or violates any law, please contact pure-support@ulster.ac.uk. 


\title{
Endothelial Cell Growth on Silicon Modified Hydrogenated Amorphous Carbon Thin Films
}

\author{
A. A. Ogwu, ${ }^{1 \star}$ T. I. T. Okpalugo, ${ }^{1}$ N. $A{ }^{2}{ }^{2}$ P. D. Maguire, ${ }^{1}$ J. A. D. McLaughlin ${ }^{1}$ \\ ${ }^{1}$ NIBEC, School of Electrical and Mechanical Engineering, University of Ulster at Jordanstown, \\ Shore Road, Co. Antrim, BT37 0QB, Northern Ireland, UK \\ 2 Department of Mechanical Engineering, University of Aveiro, Aveiro, Portugal
}

Received 12 August 2005; revised 2 May 2007; accepted 29 May 2007

Published online 21 August 2007 in Wiley InterScience (www.interscience.wiley.com). DOI: 10.1002/jbm.b.30922

\begin{abstract}
The biological response of human microvascular endothelial cells (HMEC-1) seeded on Si-DLC films and on control surfaces was evaluated in terms of initial cell enhancement, growth, and cytotoxicity. The microstructure of the films was characterised by Raman spectroscopy and X-ray photoelectron spectroscopy. The effect of changes in microstructure, surface energy, surface electronic state, and electronic conduction, on the biological response of the films to endothelial cells was investigated. Endothelial cell adhesion and growth was found to be affected by changes in the microstructure of the films induced by silicon doping and thermal annealing. We observed a significant statistical difference in endothelial cell count between the as-deposited DLC and Si-DLC films using the one sample $t$ test at a $p$-value of 0.05 . We also found a statistically significant difference between the adhesion of HMEC films on DLC and Si-DLC films at various annealing temperatures using the one-way ANOVA $F$ statistic test at $p<0.05$ and the post-hoc Tukey test. One sample $t$-test at $p<0.05$ of MTT-assay results showed the endothelial cells to be viable when seeded on DLC/ Si-DLC films. We suspect that the increased adhesion of endothelial cells induced by increasing the amount of silicon in the Si-DLC films is associated with the development of a suitable surface energy due to silicon addition, which neither favored cell denaturing nor preferential water spreading before cellular attachment on the film surface. The presence of an external positively charged dipole on the Si-DLC films confirmed by our Kelvin probe measurements is also expected to enhance the adhesion of endothelial cells that are well known to carry a negative charge. The Si-DLC films investigated hold potential promise as coatings for haemocompatible artificial implants. (C) 2007 Wiley Periodicals, Inc. J Biomed Mater Res Part B: Appl Biomater 85B: 105-113, 2008
\end{abstract}

Keywords: blood-material interaction; cell adhesion; carbon coatings; endothelial cells; hydrophobic; surface modification

\section{INTRODUCTION}

The sustained function of the natural grafts is attributed to the presence of viable endothelial cells on the luminal surface. ${ }^{1}$ For narrow diameter synthetic vascular grafts $(<6$ $\mathrm{mm}$ ) and other potential blood contacting devices that are thrombogenic, the current trend is to apply cell-seeding of the endothelial cells onto the surfaces to reduce thrombogenicity. ${ }^{1}$ The endothelial lining has also been reported to be

Correspondence to: A. A. Ogwu (e-mail: ogwu-ph0@paisley.ac.uk) or T. I. T. Okpalugo (e-mail: thomas.okpalugo@paisley.ac.uk)

*Present address: Thin Film Centre, Paisley University, High Street, Paisley, PA1 2BE, Scotland, UK

(C) 2007 Wiley Periodicals, Inc. the best nonthrombogenic surface. ${ }^{2}$ Pyrolytic carbon, when alloyed with silicon, shows excellent thrombo-resistance., Our current investigation is aimed at evaluating the potential of a more readily available synthetic silicon modified carbon film (Si-DLC) for thrombo-resistant applications. Our initial investigation is therefore directed at evaluating the adhesion and spreading of microvascular endothelial cells on the surface of the Si-DLC films. This is promising regarding future applications involving possible in vitro growth of endothelial cells on Si-DLC coated devices before the implantation of such devices in the human body. The present investigation is directed at understanding the effect of surface energy, thermal annealing, and electrical property/work function (WF) on the endothelial cell compatibility of DLC films,${ }^{5-15}$ through a modification of the DLC films by silicon (Si-DLC). 


\section{EXPERIMENTAL WORK}

\section{Film Deposition}

Hydrogenated and silicon modified hydrogenated amorphous carbon films were prepared using a Diavac RF (13.56 MHz) PECVD system with negative electrode self bias voltages between 100 and 500 V. Deposition was carried out with argon and acetylene gases for the formation of hydrogenated amorphous carbon (DLC) films under plasma glow discharge and tetramethysilane (TMS) vapor was introduced as a third gas phase for the deposition of silicon modified DLC films. The gas flow rates of argon and acetylene was varied between 10 and $20 \mathrm{sccm}$, respectively, and for the silicon modified films the flow rate of TMS was varied up to a maximum of $20 \mathrm{sccm}$. The deposition was carried out on argon-cleaned (100) p-type and ntype silicon substrates. The deposition parameters used for our investigation are as shown in Table I.

\section{Raman Spectroscopy and XPS Measurements}

An ISA-Labram equipment was used for Raman measurements. The excitation was achieved using an internal $20 \mathrm{~mW}$ Helium-Neon (He-Ne) laser with a wavelength of $632.82 \mathrm{~nm}$ and an external $50 \mathrm{~mW}$ argon ion laser with a wavelength of $514.53 \mathrm{~nm}$. The curve fitting of the Raman spectrum involved the use of a second order polynomial function for baseline correction and the D- and G peak position was fitted with two Gaussian functions. X-ray photoelectron spectroscopy (XPS) measurement was carried out using a KRATOS XSAM 800 equipped with an energy analyzer. The X-ray source employed was a $\mathrm{Mg} \mathrm{K} \alpha$ at $15 \mathrm{keV}$ and $20 \mathrm{~mA}$. The base pressure within the spectrometer during examination was better than $8 \times 10^{-10}$ mbar.

\section{Surface Energy and Contact Angle Measurements}

The Cahn Dynamic angle analyzer model DCA-322 manufactured by Cahn instruments of Wisconsin, USA was used for our dynamic contact angle measurement. An IBM-compatible computer was interfaced to the DCA-322 equipment for data analysis and display using the Win DCA software program in a windows based environment. Measurements of advancing and receding contact angles, and surface ener- gies were conducted. Complementary sessile drop contact angle measurement was also carried out on the as deposited films using the KSV CAM 200 optical contact angle meter. The surface energy values were calculated with the results of contact angle measurements, obtained using two liquids namely water (polar) and diiodomethane (dispersive) by the Wilhemy plate technique. The films were deposited to obtain a complete coverage of both surfaces of silicon plates glued back to back and glass cover slides before immersion to obtain the advancing and the receding contact angle values. Measurements using distilled water as the liquid were also conducted by the direct optical method for contact angle measurement to complement the Wilhemy plate measurements.

\section{Electrical and Kelvin Probe Measurements}

Current-voltage $(I-V)$ measurements were carried out on the films using a metal-semiconductor-metal (MSM) sandwich with a Keithley model 485 digital picoammeter. The slope of the forward current taken from the ohmic region of the current-voltage curve gave the reciprocal of resistance, $R^{-1}$. The contact potential difference (CPD)/WF measurements were carried out using the Kelvin probe technique approach of Baikie and Estrup ${ }^{16}$ under ambient conditions.

Details of the $I-V$ and Kelvin probe setup have been reported elsewhere. ${ }^{16,17}$

\section{Thermal Annealing}

Thermal treatment of the as-deposited films on silicon substrates was carried out in an alumina tube furnace under an atmosphere of flowing nitrogen gas for $2 \mathrm{~h}$. The temperature range for the thermal treatment was between 200 and $600^{\circ} \mathrm{C}$. The samples were placed in a clean alumina tray to avoid contamination and after treatment the samples were left to cool under flowing nitrogen gas before removal.

\section{Cell Culture}

Human microvascular endothelial cell (HMEC-1) line from foreskin tissue was obtained from the molecular biology department of the University of Ulster at Jordanstown, Northern Ireland. Cell cultures were maintained in MCDB-

TABLE I. Deposition Conditions for the DLC and Si-DLC Film

\begin{tabular}{lccccc}
\hline Sample & DLC & SD5 & SD10 & SD15 & SD20 \\
\hline DC-volts (V) & 400 & 400 & 400 & 400 & $\sim 00$ \\
RF-power (W) & $\sim 150$ & $\sim 160$ & $\sim 165$ & $\sim 175$ & $\sim 210$ \\
Temperature ( ${ }^{\circ}$ ) & Ambient & Ambient & Ambient & Ambient & Ambient \\
Pressure (base) (torr) & $6 \times 10^{-6}$ & $6 \times 10^{-6}$ & $6 \times 10^{-6}$ & $6 \times 10^{-6}$ & $6 \times 10^{-6}$ \\
Gas ratio (sccm) Ar: $\mathrm{C}_{2} \mathrm{H}_{2}: \mathrm{TMS}$ & $10: 20: 0$ & $10: 20: 5$ & $10: 20: 10$ & $10: 20: 15$ & $10: 20: 20$ \\
Pressure (deposition) (mtorr) & $\sim 1.3 \times 10^{-2}$ & $\sim 1.9 \times 10^{-2}$ & $\sim 2.7 \times 10^{-2}$ & $\sim 3.2 \times 10^{-2}$ & $\sim 4.5 \times 10^{-2}$ \\
Time (deposition) (min) & 5 & 5 & 5 & 5 & 5 \\
\hline
\end{tabular}

The numbers in SD5, SD10, SD15, and SD20 represents the flow rates of TMS in sccm used during deposition. 
131 media supplement with L-Glutamine (200 mM), 10\% foetal calf serum, epidermal growth factor $(10 \mathrm{ng} / \mathrm{mL})$, penicillin $(20 \mathrm{IU} / \mathrm{mL})$, and streptomycin $(20 \mu \mathrm{g} / \mathrm{mL})$. Cells were grown as monolayers in tissue culture flasks at $37^{\circ} \mathrm{C}$ under $5 \% \quad \mathrm{CO}_{2} / 95 \%$ air. Proteins were removed with two washings of phosphate buffered saline (PBS). Harvesting of cells for subculturing or tests was performed with a trypsin solution. Shortly afterwards, the trysin was inactivated with the culture media and by centrifugation supernatants were separated from the cells. Cells were used when they were about confluent and under exponential growth phase. The samples were sterilized with $70 \%$ ethanol before they were taken into the hood and given sufficient time to dry inside the hood (and afterwards rinsed with PBS or distilled water). Every normal culturing sterility precaution was taken throughout the experiment. About $4 \times 10^{5}$ cells $/ \mathrm{mL}$ were seeded on top of the DLC and Si-DLC samples placed inside the petri-dishes, and about $1 \times 10^{3}$ cells $/ \mathrm{mL}$ were seeded into the wells of the 96-well culture plates that were coated with DLC and Si-DLC. The uncoated samples were used as control. For the MTT-assay some control wells were also created and marked blank. The cells for the MTT-assay were seeded for a total of about $56 \mathrm{~h}$. The cells on the silicon wafer substrates were fixed with $2.5 \%$ glutaraldehyde in $0.1 \mathrm{M}$ phosphate solution for $5 \mathrm{~min}$, followed by $1 \%$ osmium tetraoxide in $0.1 \mathrm{M}$ phosphate solution for $5 \mathrm{~min}$. The samples were dried with increasing concentrations of ethanol successively and finally with hexamethyldisilaxane.

\section{MTT-Assay}

MTT (3-(4,5-dimethylthiazol-2-yl)-2,5-diphenyl tetrazolium bromide) was dissolved in PBS at $5 \mathrm{mg} / \mathrm{mL}$ concentration and filter sterilized inside the hood to remove a small amount of insoluble residues usually present in some batches of MTT. About $5 \mathrm{~h}$ before the end of the incubation period, $20 \mu \mathrm{L}$ of MTT solution was added to each well including the blank wells (wells with added media, but no added cells). The plates were then transferred back to the incubator $\left(37^{\circ} \mathrm{C}\right)$ for $5 \mathrm{~h}$. After the incubation period the media was gently removed from all the wells with a syringe/needle and $200 \mu \mathrm{L}$ of DMSO was added to each of the wells (DMSO was handled in the dark, because it is unstable in the light). The plates were returned to the incubator for $5 \mathrm{~min}$ to dissolve air bubbles. These samples were then transferred to the Titertek+plus MS2 microELISA reader and the optical densities were read using a test wavelength of $550 \mathrm{~nm}$ and a reference wavelength of $660 \mathrm{~nm}$. The plates were read within $1 \mathrm{~h}$ of adding DMSO.

\section{Scanning Electron Microscopy}

The Hitachi S-3200N scanning electron microscope was used to observe the interaction between endothelial cells and the Si-DLC films on silicon substrates. The samples were coated with a conducting (gold-platinum) layer of less than $30 \mathrm{~nm}$ thickness, using a Polaron-E5000 SEM (scanning electron microscopy) sample coating unit to reduce surface charging and obtain a better contrast during SEM-imaging. The conditions used for the SEM-imaging were $5.0 \mathrm{kV}$ and $\times 200$ magnification.

\section{Stereological Investigation}

The cells number counting over an area of $600 \times 400 \mu \mathrm{m}$ on the SEM image of various samples were performed using the UTHSCSA, ImageTool programme developed in the department of dental diagnostic science at the University of Texas Health Science Center, San Antonio, by Wilcox et al. ${ }^{18}$

\section{Statistical Analysis}

The SPSS software version 12.0.1 for windows was used for the statistical analysis. The adhesion of the HMEC cells on control and DLC/Si-DLC coated substrates was analyzed using the one-sample $t$-test. The viability of the HMEC cells using the MTT assay test to compare a control surface with DLC/Si-DLC coated surfaces was also evaluated with a one sample $t$-test, with both investigations considered at a $p$-value of $<0.05$. The one way ANOVA test was used to consider the effect of temperature on the adhesion of HMEC cells to DLC and Si-DLC films at a $p$ value of $<0.05$, whilst the post-hoc Tukey test was used to identify the significant mean differences.

\section{EXPERIMENTAL RESULTS}

\section{Raman Spectroscopy}

Raman spectroscopy investigation was conducted on both the as obtained and the thermally annealed DLC and SiDLC films. The thermal annealing was conducted at temperatures between 200 and $600^{\circ} \mathrm{C}$ under a flowing nitrogen atmosphere for $2 \mathrm{~h}$. The information collected from the Raman spectroscopy investigation included the Ramanpeak intensities for the D- and G-peaks, that is $I_{\mathrm{D}}$ and $I_{\mathrm{G}}$ peaks, the $I_{\mathrm{D}} / I_{\mathrm{G}}$ ratios and the full-width at half maximum for both peaks as shown in Table II. The results of the Raman spectroscopy show an increase in the $I_{\mathrm{D}} / I_{\mathrm{G}}$ ratios (Figure 1) with annealing temperature for the DLC and SiDLC films in agreement with earlier reports in the literature. ${ }^{19}$ The increase in $I_{\mathrm{D}} / I_{\mathrm{G}}$ ratio on the annealing of DLC has been associated with the growth of crystallite structures in the DLC thin film. In the DLC films the increase in the $I_{\mathrm{D}} / I_{\mathrm{G}}$ ratio with thermal annealing is linear, but for the $\mathrm{Si}$ DLC films the $I_{\mathrm{D}} / I_{\mathrm{G}}$ ratio increase occurred only at relatively higher annealing temperatures of $300^{\circ} \mathrm{C}$ and above. The $I_{\mathrm{D}} / I_{\mathrm{G}}$ ratio also decreases with increasing amount of silicon in the films as shown in Figure 1. Physical and chemical changes in carbon materials resulting in graphitization occurs during thermal annealing. Graphitization is associated with an increased $\mathrm{sp}^{2}$ content, while silicon 
TABLE II. Raman Features of a-C:H and a-C:H:Si Thin Films

\begin{tabular}{|c|c|c|c|c|c|c|c|c|}
\hline Bias volt (V) & TMS (sccm) & $I_{\mathrm{D}}(\mathrm{au})$ & $I_{\mathrm{G}}(\mathrm{au})$ & FWHM (D) & FWHM (G) & $I_{\mathrm{D}} / I_{\mathrm{G}}$ & D-Peak $\left(\mathrm{cm}^{-1}\right)$ & G-Peak $\left(\mathrm{cm}^{-1}\right)$ \\
\hline 400 & 5 & 1231.7 & 4397.6 & 211 & 104.6 & 0.28 & 1336.48 & 1504.99 \\
\hline 400 & 10 & 1383.2 & 6396.5 & 192.8 & 103.5 & 0.21 & 1310.1 & 1490.07 \\
\hline 400 & 15 & 2206.7 & 9687.6 & 198.8 & 103.4 & 0.22 & 1296.36 & 1483.18 \\
\hline 400 & 20 & 1584.4 & 8423.5 & 205.5 & 102.7 & 0.18 & 1278.99 & 1477.16 \\
\hline 400 & 0 & 1775.9 & 4501.8 & 194.8 & 108.5 & 0.39 & 1349.5 & 1541.96 \\
\hline
\end{tabular}

doping tends to increase the number of $\mathrm{sp}^{3}$ sites. ${ }^{19}$ Silicon does not form $\pi$-bonds and it therefore increases the number of $\mathrm{sp}^{3}$ sites in the Si-DLC films. The presence of silicon in the Si-DLC film structure results in the creation of new defect states in the band gap of the films through the formation of $\mathrm{sp}^{3}$ cluster sites. ${ }^{19}$ This reduces the WF and electron affinity of the Si-DLC films and improves the endothelial cell adhesion as reported later in this article.

\section{XPS Investigation}

The XPS investigation further confirmed the presence of silicon rich $\mathrm{sp}^{3}$ sites as shown by Raman spectroscopy. Typical XPS chemical analysis for the as deposited and annealed DLC and Si-DLC films are as indicated in Table III. The peak binding energies of the films are consistent with those reported in the literature by Dementjev et al., ${ }^{20}$ Grill et al., ${ }^{21}$ Constant and Le Normand, ${ }^{22}$ and Baker and Hammer. $^{23}$ The percentage atomic concentration of $\mathrm{Si}$ increased from $0.36 \%$ (undoped) to $10.5 \%$ as the TMS flow rate increased from 0 to $20 \mathrm{sccm}$. There is a rapid rise in $\mathrm{Si}$ atom incorporation initially as the TMS flow is increased, but this is not followed by a continuous rapid increase as the TMS flow rate is increased continuously. On the other hand the $\mathrm{C}$ atom percentage concentration

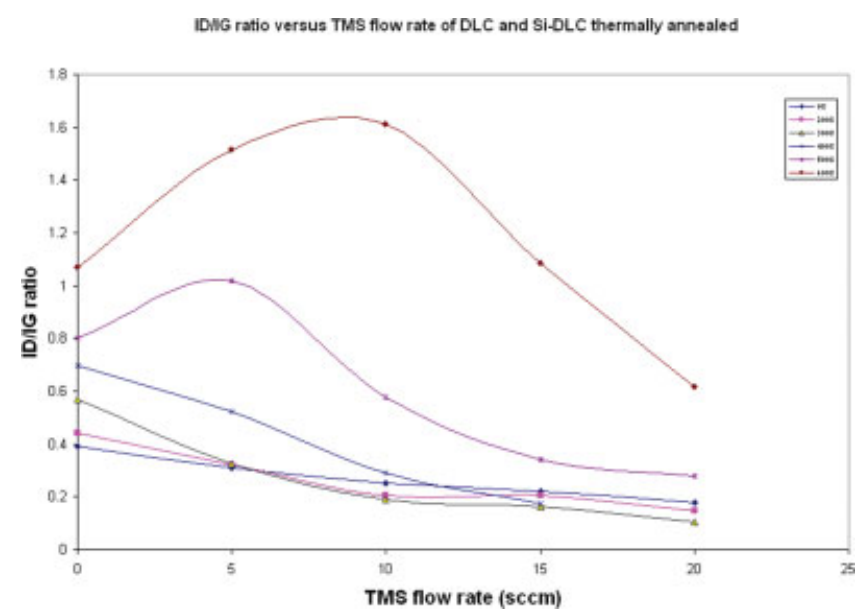

Figure 1. Raman $I_{D} / l_{G}$ ratios for the DLC and Si-DLC films both nonannealed and thermally annealed $\left(200-600^{\circ} \mathrm{C}\right)$ under flowing nitrogen for $2 \mathrm{~h}$ versus the TMS flow rate during deposition. [Color figure can be viewed in the online issue, which is available at www.interscience.wiley.com.] decreased with $\mathrm{Si}$ atom incorporation and/or substitution. There was only a slight change in the values of the binding energies for the silicon-modified films even after annealing to $600^{\circ} \mathrm{C}$. We also observed an increase in $\mathrm{sp}^{3} / \mathrm{sp}^{2}$ ratios after peak deconvolution. This is due in part to $\mathrm{Si}$ and hydrogen addition/substitution in the $\mathrm{C}$ matrix and the effects of this in the chemical and physical properties of the film is related to the corresponding difference in their endothelial cellular response.

\section{Electron Conduction}

Typical I-V curves of the MSM sandwich (Figure 2) shows that the electrical conduction mechanism is not simple ohmic but semi-conducting. We observed that silicon addition to DLC lowers it's resistivity. Thermal annealing of both DLC and Si-DLC leads to a decrease in resistivity (Figure 3), which is likely to be associated with microstructural changes as indicated by the $\mathrm{sp}^{3} / \mathrm{sp}^{2}$ ratio changes observed for the annealed films by Raman spectroscopy.

At $600^{\circ} \mathrm{C}$ annealing temperature, the conductivity of both DLC and Si-DLC becomes simple Ohmic. This result is consistent with the Raman spectroscopy investigation, which revealed graphitization at this annealing temperature. The increasing graphitic content of the films at an annealing temperature of $600^{\circ} \mathrm{C}$ increases the proportion of delocalized $\pi$-bonded electrons and therefore increases the electrical conductivity of the films at this annealing temperature, which results in the ohmic-behavior.

\section{Surface Energy and Contact Angle Measurement}

The contact angle measurement results obtained using the optical method are as shown in Figure 4 and the results of the surface energy measured by the Wilhemy plate technique for films deposited on silicon substrates are as shown in Table IV. Silicon doping leads to an increase in the contact angles as shown in Figure 4. Silicon doping also results in a slight reduction of the surface energy values as shown in Table IV.

As shown in Figure 5(a), there seems to be fewer number of cells visible on the undoped DLC films compared with those of the silicon modified DLC films Figure 5(b).

The measured contact angle for the nondoped DLC film is $72^{\circ}$ (which is lower than those of Si-DLC, Figure 4). 
TABLE III. XPS Chemical Analysis and Binding Energies (BE) of Elements in the as-Deposited DLC and Si-DLC Thin Films

\begin{tabular}{lccccrr}
\hline Sample & $\mathrm{C}(\%)$ & Peak BE $(\mathrm{eV})$ & $\mathrm{O}(\%)$ & Peak BE $(\mathrm{eV})$ & Si $(\%)$ & Peak BE $(\mathrm{eV})$ \\
\hline DLC/undoped/400V & 89.58 & 285.11 & 10.07 & 532.51 & 0.36 & 102.41 \\
DLC(SD5)/400V & 82.83 & 285.01 & 12.21 & 533.31 & 4.96 & 101.51 \\
DLC(SD10)/400V & 79.07 & 285.09 & 13.32 & 533.09 & 7.61 & 101.29 \\
DLC(SD15)/400V & 76.57 & 285.10 & 13.80 & 533.10 & 9.63 & 101.30 \\
DLC(SD20)/400V & 77.09 & 285.10 & 12.29 & 533.10 & 10.62 & 101.30 \\
\hline
\end{tabular}

\section{DISCUSSION}

\section{Surface Energy, Contact Potential Difference, and Work Function Measurements}

The general trend observed in our experiments based on SEM and cell counting using SEM images indicated an increase in cell adhesion with silicon addition in the SiDLC films. Contrary to earlier reports in the literature by Grinell $^{24}$ that wettable (hydrophilic) surfaces tend to be more conducive to cell adhesion, we have observed that more hydrophobic surfaces containing increasing amounts of silicon in the Si-DLC films and increasing contact angle with water, tends to promote human endothelial cell growth and adhesion on the films.

The results of the measurements of the surface energy of the DLC and Si-DLC films indicate a substantial contribution to the total surface energy by the dispersive component term, which might play a part in the cell adhesion process.

The increase in water contact angle and reduction in surface energy on the Si-DLC films compared to the DLC (i.e. a more hydrophobic surface) is expected to play a role in the observed increase in endothelial cell adhesion on the Si-DLC film surface. A more hydrophobic surface reduces it's interaction with water molecules allowing more direct contact with the endothelial cells, rather than an interaction mediated by a water layer. Kim et al., ${ }^{25}$ have also reported based on their studies on proteins and endothelial cell adhesion on amphiphilic polymer surfaces that there was a far

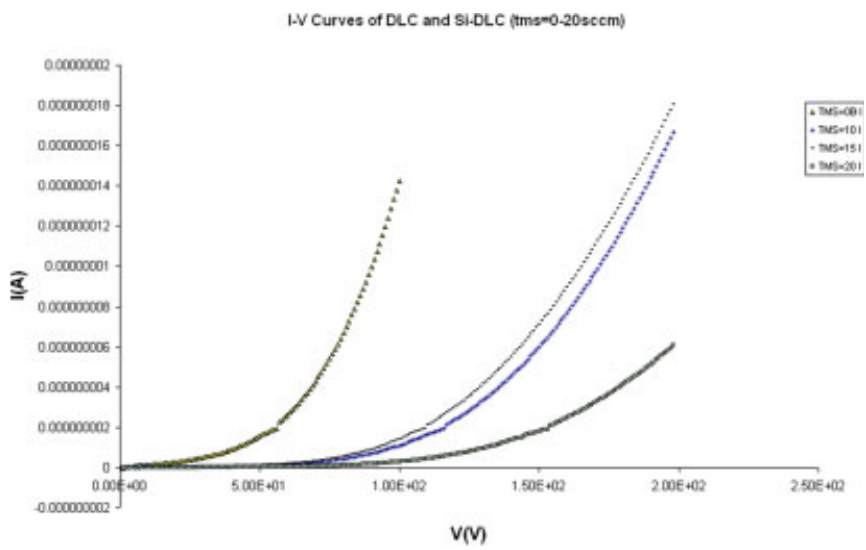

Figure 2. Typical current-voltage (I-V) curves of DLC and Si-DLC (TMS flow rate of $10 \mathrm{sccm}$ ). [Color figure can be viewed in the online issue, which is available at www.interscience.wiley.com.] more substantial adhesion of proteins on a hydrophobic surface than on a hydrophilic surface. Since a firmly bound protein layer is necessary for cell attachment, the protein adhesion to a hydrophobic surface will play a significant role in the initial cell colonization, as the first stage of a range of complex processes. Kim et al., further reported that in general cultured cells adhere to slightly hydrophobic surfaces, but there was little adhesion on either highly hydrated hydrophilic surfaces or highly hydrophobic surfaces. The present authors are also of the opinion that whilst a highly hydrophilic surface will make cell adhesion difficult through a preferential adhesion of an intermediate water layer, a highly hydrophobic surface is likely to lead to both a beading up of water molecules and a denaturing of protein and cells. We suspect that there is a fairly narrow processing window for cellular adhesion between the two extremes of hydrophilicity and hydrophobicity as obtained in this investigation with Si-DLC films and this will be the subject of our future investigations.

The CPD measures the surface potential difference between the surface of the films and the vibrating reference electrode made of brass $(\mathrm{Cu}-\mathrm{Zn})$. The relationship between the WF of the films $\phi_{\text {(film) }}$, the WF of the reference electrode $\phi_{\text {(brass) }}$ and the CPD is given by:

$$
\begin{aligned}
& \mathrm{CPD}=\phi_{\text {probe(brass) }}- \phi_{\text {sample }}=\phi_{\text {probe(brass) }} \\
&-\left[\chi+\left(E_{\mathrm{C}}-E_{\mathrm{F}}\right)_{\text {bulk }}\right]-\phi_{\mathrm{ss}} \ldots
\end{aligned}
$$

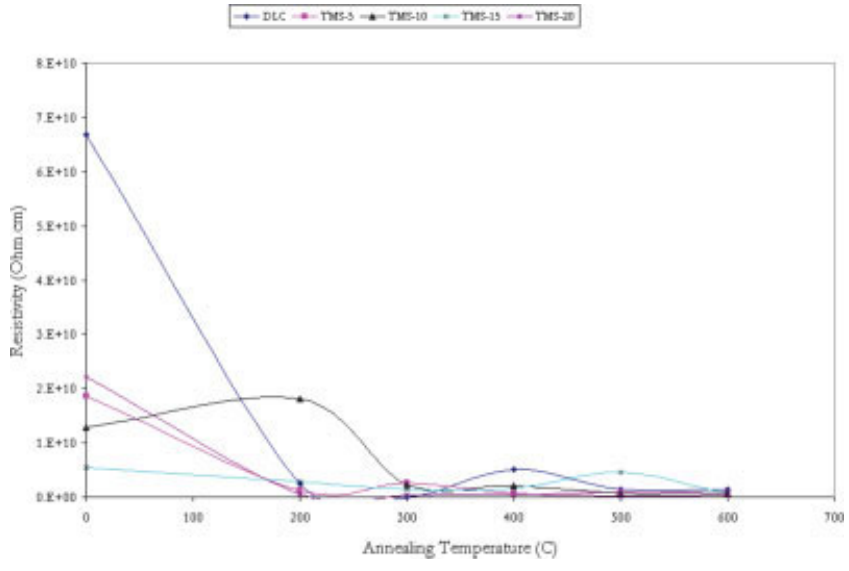

Figure 3. Resistivity versus annealing temperature of DLC and SiDLC films thermally annealed at $200-600^{\circ} \mathrm{C}$ (on $x$-axis 0 indicates room temperature). [Color figure can be viewed in the online issue, which is available at www.interscience.wiley.com.] 


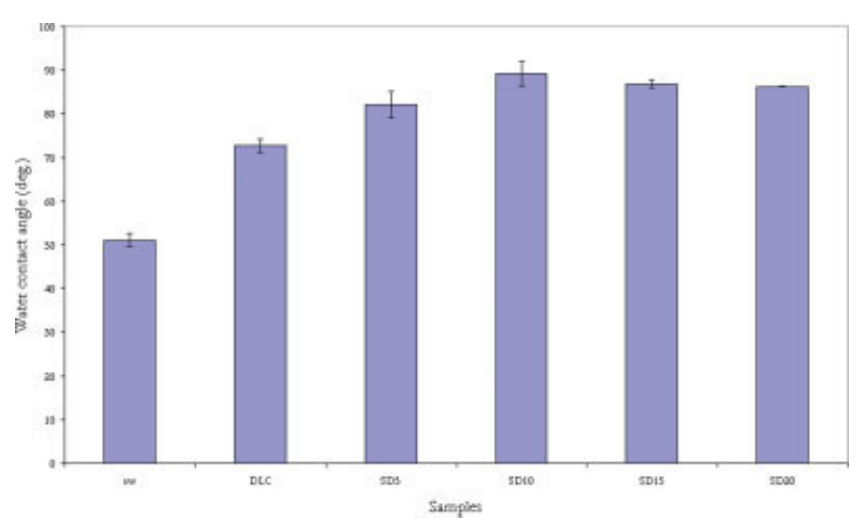

Figure 4. Contact angle in water using direct optical technique. [Color figure can be viewed in the online issue, which is available at www.interscience.wiley.com.]

The changes in the CPD are related to changes in the electron affinity, $\chi$, band bending due to surface states $\phi_{\mathrm{ss}}$, or a shift of the bulk Fermi level $\left(E_{\mathrm{C}}-E_{\mathrm{F}}\right)_{\mathrm{b}}$. If $\chi$ remains constant, then the changes in the CPD are directly related to the shift of the Fermi level in the bulk material and band bending in the surface states. ${ }^{26-28}$

We have carried out CPD measurements on the DLC and Si-DLC films. The CPD measurements represent the surface potential difference between the surface of the films and the vibrating reference electrode made of brass $(\mathrm{Cu}-\mathrm{Zn})$. The result of the work-function measurements is as shown in Figure 6. The WF decreased with silicon addition. The decrease in WF values has also been associated with a reduction in the net surface dipole. ${ }^{29} \mathrm{Bolz}$ and Schaldach $^{14}$ have already proposed that the early stages of thrombus formation are preceded by an electron transfer oxidation process, resulting in the transformation of fibrinogen to a fibrin polymer. We observed a substantial increase in the number of adherent endothelial cells in the Si-DLC compared to the DLC films as shown in Figure 7, but further silicon addition did not lead to any substantial change in the number of adherent cells on the Si-DLC film surface. The result of the one sample $t$-test revealed a significant difference between the HMEC adhesion to the uncoated and the DLC/Si-DLC coated surfaces at a $p$-value $<0.05$. It has been suggested that the cell adhesion process depends on the sign of the charge carried by the adherent cell. Positively charged surfaces will attract cells with a negative charge or dipole and vice versa. ${ }^{14}$

Klein et al. ${ }^{30}$ have reported that vascular endothelial cells have a highly negatively charged surface, while Bowlin and Rittger ${ }^{9}$ confirmed that endothelial cell adhesion is enhanced by the presence of a temporarily induced surface positive charge on a PTFE graft material. The reduction in WF of the Si-DLC films compared to the asprepared DLC films, we believe is associated with the creation of new defect states in the band-gap of the Si-DLC films through the formation of clusters like the $\mathrm{sp}^{3}$ rich $\mathrm{Si}-$ $\mathrm{H}$ clusters. The presence of silicon and hydrogen in the hydrogenated DLC (a-C:H) films, that are more electropositive than carbon ${ }^{29,31}$ will result in the formation a surface dipole with an external positively charged side on the silicon doped DLC film. Electropositive elements like caesium are well known to reduce the WF of more electronegative surfaces. This is an effect that is well used to enhance thermionic emission. It is the positive end of the dipole on the surface of the Si-DLC films that is believed to be responsible for anchoring the negatively charged endothelial cells.

\section{Cell Adhesion on Thermally Annealed Films}

The results of the cell count analysis, giving an indication of the adherent cell population against the annealing temperatures are as shown in Figure 8(a-c).

There is a considerable drop in the population of adherent human endothelial cells for DLC thermally annealed at $600^{\circ} \mathrm{C}$ compared to the film annealed at $200^{\circ} \mathrm{C}$ as shown in Figure 8(a). The Raman spectrum of the film annealed at $600^{\circ} \mathrm{C}$ indicates a substantial graphitization, and this is also the case for the film annealed at $500^{\circ} \mathrm{C}$. Annealing DLC at 500 and $600^{\circ} \mathrm{C}$ leads to a substantial graphitization and our current observation is that this does not appear favorable for human endothelial cell adhesion and growth, although the graphite phase is associated with an improvement in electrical conduction. For the Si-DLC samples annealed between 200 and $600^{\circ} \mathrm{C}$, there was a fairly consistent population of endothelial cells for the 5 and $10 \mathrm{sccm}$ TMS flow rate films as shown in Figure 8(b,c). The Levene statistic was used as a part of the one-way ANOVA Test, to test for the

TABLE IV. Surface Energy and Contact Angle Measurements for the Films Deposited on Silicon Substrates

\begin{tabular}{lcccccc}
\hline TMS $(\mathrm{sccm})$ & Bias Volt $(\mathrm{V})$ & $\theta_{\text {adv water }}\left({ }^{\circ}\right)$ & $\theta_{\text {rec water }}\left({ }^{\circ}\right)$ & $\gamma_{\mathrm{P}}(\mathrm{m} N / \mathrm{m})$ & $\gamma_{\mathrm{D}}(\mathrm{n} M / \mathrm{m})$ & 41.05 \\
\hline DLC & 400 & 88.01 & 55.32 & 1.17 & 41.53 \\
SD5 & 400 & 82.12 & 49.27 & 2.5 & 42.22 \\
SD10 & 400 & 89.54 & 27.7 & 1.5 & 35.73 \\
SD15 & 400 & 90.76 & 41.48 & 1.24 & 35.88 \\
\hline
\end{tabular}

$\gamma_{\mathrm{P}}$, polar components; $\gamma_{\mathrm{D}}$, dispersive components; and $\gamma_{\mathrm{S}}$, total surface energy. 

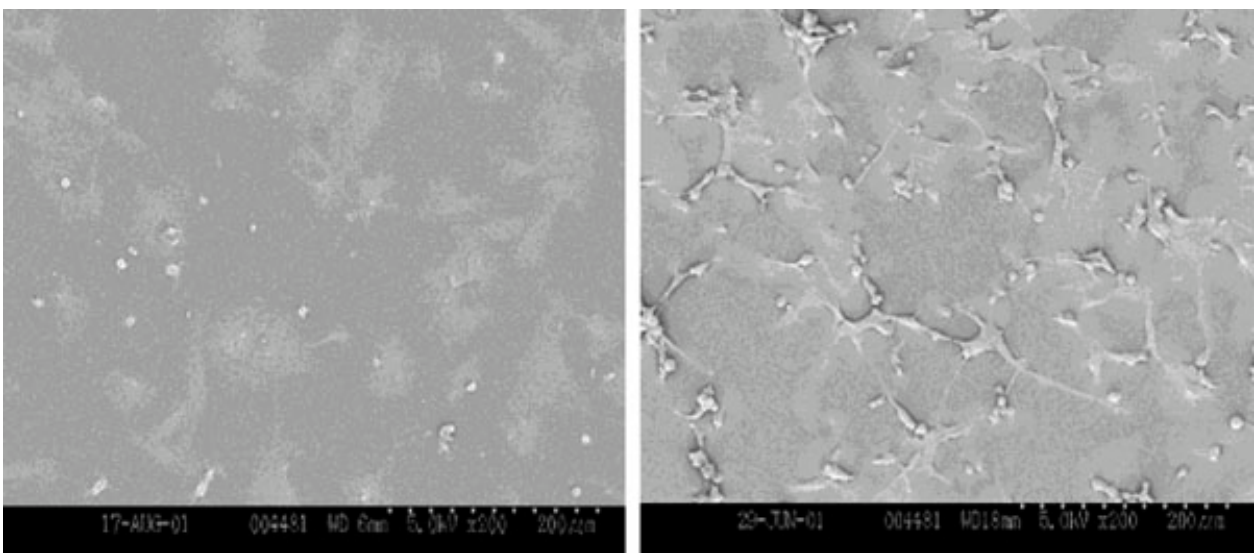

Figure 5. (a) SEM image of DLC seeded with endothelial cells for $\sim 6 \mathrm{~h} ; \times 200$ : (b) Si-DLC (TMS flow rate of $5 \mathrm{sccm}$ ) seeded with endothelial cells for $\sim 6 \mathrm{~h} ; \times 200$.

homogeneity of variance of the HMEC cell count on the surfaces investigated. At a $p$-value of $<0.05$, the Levene statistic indicated that there was no evidence for the heterogeneity of variance. The ANOVA $F$-test gave a value of 7.869 indicating a difference between the group means of the HMEC adhesion to the samples investigated at a $p$-value of $<0.05$. The post-hoc Tukey's test puts the mean values of HMEC cells obtained on the DLC films in a different subset from those of the Si-DLC films at the temperatures investigated. In all the cases investigated for the DLC and Si-DLC films, we observed a direct correlation between electronic conduction in the films and the population of adherent human endothelial cells whenever there was no significant graphitization detectable by Raman spectroscopy. However, even when electronic conduction was relatively high in the films, graphitization in such films always led to a substantial reduction in the population of adherent endothelial cells on it's surface.

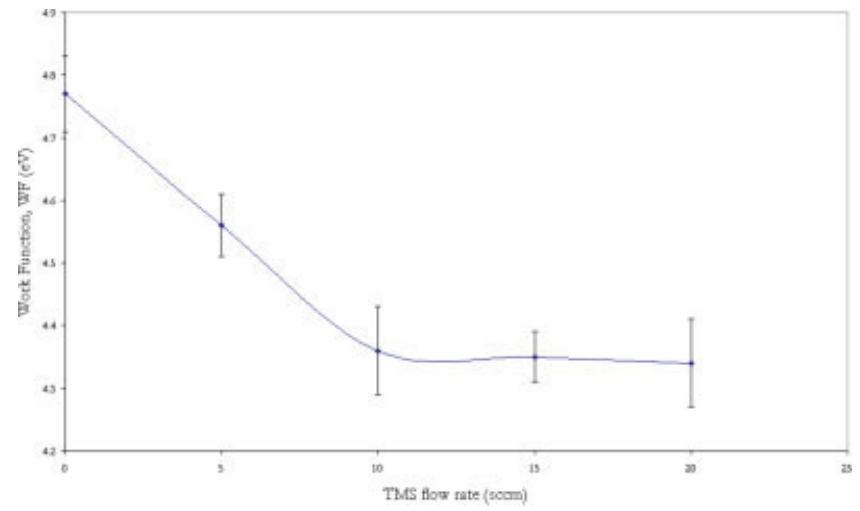

Figure 6. Work function results of DLC and Si-DLC. [Color figure can be viewed in the online issue, which is available at www. interscience.wiley.com.]

\section{Cytotoxicity: MTT-Assay Results}

The results of the MTT-assay shown in the histogram in Figure 9, gives the optical density (OD) of the active cells in culture after $56 \mathrm{~h}$. The assay detects metabolism in the living cells and the intensity obtained is dependent on the degree of activity of the cells. ${ }^{32}$ The histogram (Figure 9) shows the result of the optical density obtained from viable cells in the wells coated with DLC and a-C:H:Si, indicating intracellular activity and/or proliferating potential of the endothelial cell in these samples. The uncoated TCPS was used as a control. The frequency distributions of the OD-values are near Gaussian-normal distribution (expected in randomly sampled and seeded living cells/tissues over 96 wells), although there is typical variation in OD-values from well to well. ${ }^{33}$ The result of the one sample $t$-test showed that cell viability was not significantly different $(p<0.05)$ between the control and DLC/Si-DLC coated surfaces. This shows that the coatings are not cytotoxic

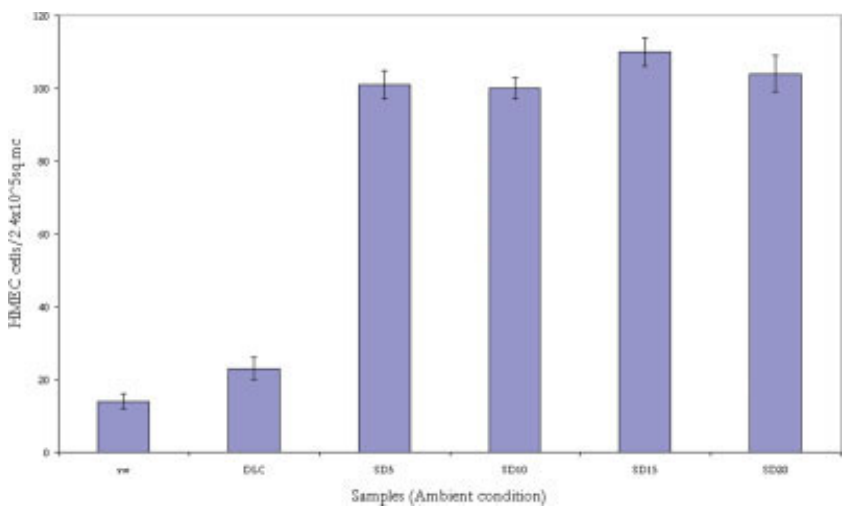

Figure 7. Human microvascular endothelial cells (HMEC-1) adhesion on DLC and Si-DLC as obtained (ambient condition, unannealed samples). [Color figure can be viewed in the online issue, which is available at www.interscience.wiley.com.] 
to the cells. Generally, these samples could be said to be closely compatible when compared to the noncoated sample. However, it is possible that the coated wells gave a slightly lower HMEC activity due to the fact that the TCPS-substrate material was subjected to predeposition
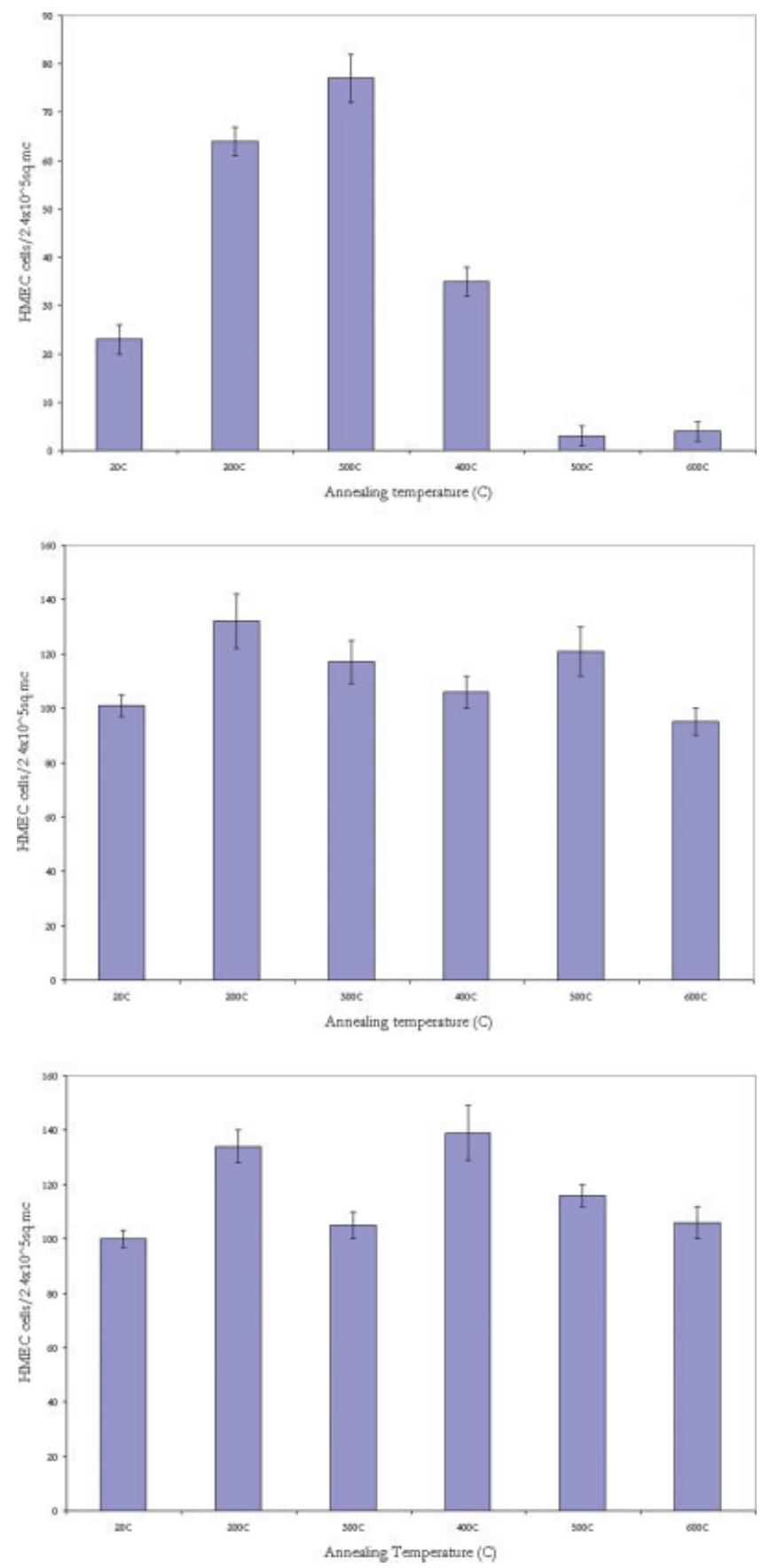

Figure 8. (a) Human endothelial cell adhesion on DLC (as deposited and thermally annealed, $200-600^{\circ} \mathrm{C} ; 20^{\circ} \mathrm{C}=$ ambient temperature); (b) Si-DLC (TMS flow rate, $5 \mathrm{sccm}$, as deposited and thermally annealed, $200-600^{\circ} \mathrm{C} ; 20^{\circ} \mathrm{C}=$ ambient temperature); (c) Si-DLC (TMS flow rate, $10 \mathrm{sccm}$, as deposited and thermally annealed, 200$600^{\circ} \mathrm{C} ; 20^{\circ} \mathrm{C}=$ ambient temperature). [Color figure can be viewed in the online issue, which is available at www.interscience.wiley.com.]

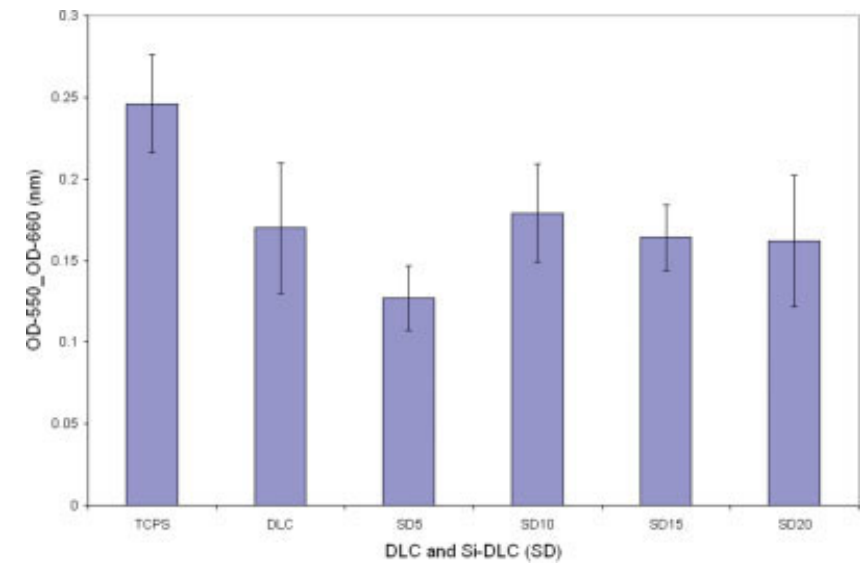

Figure 9. Histogram of MTT-assay of HMEC seeded on 96 well culture plates that were coated with DLC and Si-DLC (TMS flow-rate, 5-20 sccm, SD 5-20). [Color figure can be viewed in the online issue, which is available at www.interscience.wiley.com.]

atomic argon (at $400 \mathrm{~V}$ ) cleaning, which may have affected the soft polymer substrate. ${ }^{33}$

\section{CONCLUSION}

We have carried out investigations into the effect of changes in microstructure, electronic conduction, WF, surface energy, and thermal annealing on the endothelial cell compatibility of Si-DLC films. We observed a direct correlation between adherent cell population on the Si-DLC films and electronic conduction. This correlation does not hold when graphitization, which is detected by Raman spectroscopy, has occurred in the Si-DLC films regardless of their electronic conductivity. The microstructural variation in the films was achieved by varying silicon content and by thermal annealing. Silicon modification produced a surface energy region which favored cellular attachment to the Si-DLC film surface. The improved adhesion of the endothelial cells to the Si-DLC film surface is further assisted by the presence of the positive end of a dipole on the $\mathrm{Si}$ DLC film surface, which will attract the negative charge carrying endothelial cells. The cytotoxicity of the endothelial cells on the Si-DLC film was measured by the MTTassay test and the cells are established to be viable after adhesion to the Si-DLC films. We are carrying out further investigations on avoiding the formation of the graphitic phase in the films and achieving full film coverage by the adherent endothelial cells. The Si-DLC films hold promise as coatings for haemocompatible artificial implants where endothelial cell presence will play a significant role.

The authors greatly appreciate assistance with the cell culture facilities from Prof. D.G Hirst, Dr. E McKenna; Dr. S.W.B Irwin, Dr. Don Saville, Dr. Tony Magee of UUJ, Jordanstown campus and Prof. NM Brown and Dr. C.A Anderson of the University of Ulster at Coleraine for assistance with XPS characterization. T. O. acknowledges a University scholarship. 


\section{REFERENCES}

1. Seifalian AM, Tiwari A, Hamilton G, Salacinski HJ. Improving the clinical potency of prosthetic vascular and coronary bypass grafts. Artif Organs 2002;26:307-320.

2. Goodman SL, Tweden KS, Albrecht RM. Platelet interaction with pyrolytic carbon heart-valve leaflets. J Biomed Mater Res 1996;32:249-258.

3. Okpalugo TIT, Ogwu AA, Maguire PD, McLaughlin JAD. Platelet adhesion on silicon modified hydrogenated amorphous carbon films. Biomaterials 2004;25:239-245.

4. Cenni E, Arciola CR. Ciapetti G, Granchi D, Savarino L, Stea S, Cavedagna D, Curti T, Falsone G, Pizzoferrato A. Platelet and coagulation factor variations induced in vitro by polyethylene terephthalate (Dacron) coated with pyrolitic carbon. Biomaterials 1995;16:973-976.

5. Soltys-Robitaille CE, Ammon DM Jr, Valint PL Jr, Grobe GL III. The relationship between contact lens surface charge and in-vitro protein deposition levels. Biomaterials 2001;22:32573260.

6. Pesakova V, Klezl Z, Balik K, Adam M. Biomechanical and biological properties of the implant material carbon-carbon composite covered with pyrolytic carbon. J Mater Sci: Mater Med 2000;11:793-798.

7. Bruinsma GM, Van der Mei HC, Busscher HJ. Bacterial adhesion to surface hydrophilic and hydrophobic contact lenses. Biomaterials 2001;22:3217-3224.

8. Ahluwalia A, Basta G, Chiellini F, Ricci D, Vozzi G. Endothelial cell adhesion on bioerodable polymers J Mater Sci: Mater Med 2001;12:613-619.

9. Bowlin GLRittger SE. Electrostatic endothelial cell seeding for small diameter $(<6 \mathrm{~mm})$ vascular prostheses: Feasibility testing. Cell Transplant 1997;6:623-629.

10. Van Wachem PB, Schakenraad JM, Feijen J, Beugeling T, Van Aken WG, Blauuw EH, Nieuwenhius P, Molenaar I. Adhesion and spreading of cultured endothelial cells on modified and unmodified poly(ethylene terephthalate): A morphological study. Biomaterials 1989;10:532-539.

11. Bruck SD. The role of electrical conduction of macromolecules in certain biomedical problems. Polymer 1975;16:25-30.

12. Bruck SD. Intrinsic semiconduction, electronic conduction of polymers and blood compatibility. Nature 1973;243:416-417.

13. Bruck SD. The relationship between unpaired spin concentration, structure, and electrical conduction of a pyrolytic aromatic polyamide. J Polym Sci Part C: Polym Symp 1967;17: $169-185$.

14. Boldz A, Schaldach M. Artificial heart valves: Improved blood compatibility by PECVD a-SiC:H coating. Artif Organs 1990;14:260-269.

15. Chen JY, Wang LP, Fu KY, Huang N, Leng Y, Leng YX, Yang P, Wang J, Wan GJ, Sun H, Tian XB, Chu PK. Blood compatibility and $\mathrm{sp}^{3} / \mathrm{sp}^{2}$ contents of diamond-like carbon (DLC) synthesized by plasma immersion ion implantationdeposition. Surf Coat Technol 2002;156:289-294.

16. Baikie ID, Estrup PJ. Low cost PC based scanning Kelvin probe. Rev Sci Instrum 1998;69:3902-3907.
17. Okpalugo TIT, Ogwu AA, Maguire PD, McLaughlin JAD. The effect of silicon doping and thermal annealing on the electrical and structural properties of hydrogenated amorphous carbon thin films. Diamond Relat Mater 2004;13:1549-1552.

18. Wilcox DC, Dove BS, McDavid DW, Greer DB. Imagetool. UTHSCSA, 1996. Available at http://ddsdx.uthscsa.edu/dig/ itdesc.

19. Ogwu AA, Lamberton RW, Morley S, Maguire P, McLaughlin J. Characterisation of thermally annealed and silicon modified DLC films by Raman spectroscopy. Phys B: Condens Matter 1999;269:335-344.

20. Dementjev AP, Petukhov MN, Baranov AM. The unique capability of X-ray photon spectroscopy in identifying the $\mathrm{sp}^{2} / \mathrm{sp}^{3}$ ratio of the surface growing carbon films. Diamond Relat Mater 1998;7:1534-1538.

21. Grill A, Meyerson B, Patel V, Reimer JA, Petrich MA. Inhomogeneous carbon bonding in hydrogenated amorphous carbon films. J. Appl Phys 1987;61:2874-2877.

22. Constant L, Le Normand. AES and XPS observations of HFCVD diamond deposition on monocrystalline (111) copper. Diamond Relat Mater 1997;6:664-667

23. Baker MA, Hammer P. A study of the chemical bonding and microstructure of ion beam-deposited $\mathrm{CN}_{\mathrm{x}}$ films including an XPS C1s peak simulation. Surf Interface Anal 1997;25:629642.

24. Grinnell F. Cellular adhesiveness and extracellular substrata. Int Rev Cytol 1978;53:65-144.

25. Kim JH, Kim SH, Kim HK, Akaike T, Kim SC. Adhesion and growth of endothelial cells on amphiphilic PU/PS IPN surface: Effect of amphiphilic balance and immobilized collagen. J Biomed Mater Res 2002:62:612-621.

26. Magill DP, Ogwu AA, McLaughlin JAD, Maguire PD. Electrical characteristics of nitrogen incorporated hydrogenated amorphous carbon. J Vac Sci Technol A 2001;19:2456-2462.

27. Hadjaj A, Cabarrocas RI, Equar B. Quantitative in situ Kelvin probe study of boron doping in a-SiC and a-SiC:H. Philos Mag B 1997;76:941-950.

28. Hadjaj A, Favre M, Equer B, Cabaroccas RI. In-situ Kelvin probe and ellipsometry study of the doping of a-Si:H and a$\mathrm{SiC}: \mathrm{H}$ layers: Correlation with solar parameters. Solar Energy Mater Sol Cells 1998;51:145-153.

29. Attard G, Barnes C. Surfaces. Oxford: Oxford University Press; 1998. pp 64-65.

30. Klein NJ, Shennan GI, Heyderman RS, Levin M. Alteration in glycosaminoglycin metabolism and surface charge on human umbilical vein endothelial cells induced by cytokines, endotoxin and neutrophils. J Cell Sci 1992;102:821-832.

31. Sutton AP. Electronic structure of Materials. Oxford: Oxford University Press; 1993. pp 34-35.

32. Wan H, Williams RL, Doherty PJ, Williams DF. The cytotoxicity evaluation of Kevlar and Silicon-carbide by MTT assay. J Mater Sci: Mater Med 1994;5:441-445.

33. Okpalugo TIT, McKenna E, Magee AC, McLaughlin JA, Brown NMD. The MTT assays of bovine retinal pericytes and human microvascular endothelial cells on DLC Si-DLCcoated TCPS. J Biomed Mater Res A 2004;71:201-208. 